\title{
The Millennium Compact and the End of Hunger \\ (transcript)
}

Speech at the World Food Prize Symposium 2003

Des Moines, October 16, 2003

\author{
By: Jeffrey D. Sachs \\ Director, The Earth Institute at Columbia University \\ Director, The United Nations Millennium Project \\ Special Advisor to the United Nations Secretary-General Kofi Annan
}

It is an enormous pleasure to be with you today. I very much admire what Ambassador Quinn, the Ruan family, and all of the others that are part of the World Food Prize Foundation are doing. It's an enormous tribute to the spirit of this state of Iowa, a place that feeds our country and much of the world, and to your commitment to fighting hunger and to advancing human well-being. To see people gathered by the hundreds to think about what we in our very blessed and very lucky country can do for human betterment is a remarkable thing; I applaud you, and I thank you for including me in this year's festivities.

It's wonderful that you're honoring Catherine Bertini, the Under Secretary-General of the United Nations, somebody that we all admire. She's done such a marvelous job in many world leadership capacities, and deserves this fantastic award. Of course, one would go anywhere in the world to have a chance to have lunch with Norman Borlaug. Norman doesn't know it, but I actually first met him 14 years ago. We were on a small plane. He would not, of course, have any reason to remember this at all, but we were on a small plane, flying from Warsaw to Gdansk in the summer of 1989. I didn't recognize him. There were only three of us getting on this airplane: the others were a colleague of mine and Professor Borlaug. I asked Norman what he did for a living, and he said that he was here to meet with some Polish officials. I myself was the economic advisor of Solidarity at the time, just as Communism was falling. Dr. Borlaug was giving them some good advice, and I said, "Oh, that's interesting. What do you do, what specifically?" He says, "Well, I work on farming." I thought that was nice, and I don't remember exactly how I asked the question, "How do you come to be here on the flight?" He said, "I got a prize." I'm not sure that I heard it, and I said, "Which prize is that?" He said, "Oh, the Nobel Peace one." And, honestly, I said, "Oh, excuse me. Who are you?" And he said he was Norman Borlaug, and I would have fallen right out of the plane had they not closed the door by then. Anyway...that was my first time meeting Dr. Borlaug.

Thinking about Poland and something Ambassador Quinn reminded me of, I wanted to share a story with you, because today is also the 25th anniversary of the election of the Pope. I was briefly his economic advisor, which was an unusual thing to be. I wasn't brought in to fix the Vatican finances, but because the Vatican issued an encyclical in 1991, called the Centesimus Annus which was a hundred-year anniversary of another encyclical called Rerum Novarum, which was about economic life and economic justice. The Pope issued this after the end of Communism in Eastern Europe, and since I was advising the Polish government, he asked me to come and discuss these issues with him, which was a very wonderful and unusual experience. 
Many years afterwards, as Ambassador Quinn was reminding me, I had the chance to come back to visit with the Pope, this time with Bono, lead singer of U2. The Pope gave an audience to talk about debt cancellation because he was with the Jubilee Movement; he was the world's spiritual leader of the notion of canceling the debts of the world's poorest countries so that they could have a chance to recover.

Two things were amazing to me then. One was being introduced to the Pope again. The bishop started to introduce me, and the Pope said, "No, no. I know who he is. We've met before." I thought that was amazing because he had probably seen a billion people in the most remarkable gatherings since we had last met. He's probably seen and been seen by more human beings than any person that's ever lived.

The other was being with Bono on this occasion and walking out of the Vatican, and we got into the back of a van and started to speed away. All of a sudden hundreds and hundreds of young people started to run after the van, which is an unusual experience, by the way. It's a little bit like those old Beatles movies, which is what it was. So I leaned over to Bono, and I said, "Bono, you know, they always do that with macroeconomists." He looked at me and said, "Yeah, right!"

Well, all of these linkages are of a common humanity attempting to figure out how to improve a world that has too many woes and too many struggles. That's really the point of the World Food Prize, and it's the point of the United Nations Millennium Development Goals that are being featured today, especially the Millennium Development Goal to reduce hunger in the world before 2015 .

A couple of years ago, our outstanding United Nations Secretary-General Kofi Annan gave me the honor to serve as his special advisor on these international development objectives, these Millennium Development Goals. These goals are quite remarkable. They were adopted by 189 world leaders that assembled on the occasion of the Millennium Summit in September of 2000. It was the largest gathering of world leaders in history. The Secretary-General put before them the Millennium Declaration which basically said, "Let's make the new millennium better than the outgoing one, in terms of our capacity to serve our fellow human beings, avoid war, and overcome the struggles and degradation of extreme poverty."

Within that Millennium Declaration were some specific challenges:

- Challenges of reducing extreme poverty, people living on less than one dollar per day, those struggling to survive day to day.

- The challenge of reducing the proportion of the nearly one billion people on the planet who don't know where their next meal is going to come from, and who live with chronic hunger, undernourishment and all of the vulnerabilities of disease and death that accompany chronic undernourishment.

- The challenge of providing human beings with the basic dignity of access to safe drinking water and sanitation. 
- The challenge of getting an estimated 200 million children at the primary school age who are not in school to complete a primary education, which we know is a limited goal, because in our world today, there's really no chance to escape from extreme poverty without at least a secondary education.

- The challenge of fighting pandemic disease. In the middle of the greatest scientific revolution of all time, millions of people are dying of preventable and treatable diseases every year. As we talk and deliberate today, 20,000 Africans will die of AIDS, TB, malaria and other readily preventable or treatable diseases.

- The challenge of ending the rampant environmental degradation that is destroying the remaining rainforests, the habitats for literally millions of species that we'll never meet because we haven't even identified them before driving them to extinction.

- The challenge of improving the quality of life of the estimated one billion people on the planet living in slums. Most of the poorest of the poor are peasant farmers living at subsistence in remote rural areas, but a growing proportion of the poor are people living in the slums of the mega-cities of impoverished countries where people are fleeing from an even worse impoverishment in the countryside and end up living in a fringe of informality, indignity, hunger, and extreme poverty within these big cities.

After describing those challenges, people usually say, "Well, that's all fine and good; that sounds like a task for a millennium, not possible in the 12 years left before 2015." But we're sitting in a room with Dr. Norman Borlaug and Dr. Swaminathan, two of the world's heroes who can say, "Those aren't big challenges. We've already done something like that!"

Despairing poverty is not an impossible challenge. It is an utterly solvable challenge, given the enormous talents and knowledge, the powerful technologies, and the proven track record that we have.

When I visited India for the first time, about 25 years ago, the books I bought on the way were still saying that India was likely to face starvation by the mid-1980s. It was a hopeless case, all these books explained. Dr. Borlaug and Dr. Swaminathan were not reading, and certainly not writing, those books. They were out applying practical knowledge based on excellent science and proven experience with very good, rigorous, serious management and good, smart politics, to get a specific job done. The job was to raise food output sufficiently so that India would not be suffering from bouts of famine and disarray. Instead, 25 years later, it has become a significant agricultural exporter and a country that could see a monsoon fail last year and more or less take it in stride - something unthinkable in earlier decades or generations in that country.

There is a great irony in the world that we're living in. Indeed, the problems are huge, and the amount of pain that is experienced daily as a result of poverty and all that it brings in its wake is enormous, perhaps so much so that I feel our leaders in this country are even too scared to look at it in the face. Yet the irony is that these are utterly solvable problems and even utterly solvable on the timetable that the United Nations set in the year 2000. 
Now the bad news: of course, we're completely off-track to achieve any of it. These are not goals that take care of themselves. These are not challenges that are met and achieved by the miracle of the market. It's like the old joke, "How many economists does it take to change a light bulb? None - the market will do it for you!" Actually, you need someone to change the light bulb. You need someone to help to fight the diseases. The diseases don't get fought on the basis of goodwill and good wishes. They get fought by applying immunizations and appropriate medicines and even simple technologies, such as anti-malarial bed nets, in appropriate places at appropriate times. These things don't happen by themselves, and we are not achieving what we have promised to achieve. We will not stand a chance of achieving it, unless we set our minds to achieving it.

After working for 25 years in dozens of the poorest countries in the world, I'm convinced that the biggest obstacle we face is the fear to look squarely at these problems. We feel that if we really were to take on the challenge of world hunger, were we really to take on the challenge of fighting AIDS or malaria, somehow our comfort levels in this country would be dissipated; we'd be drawn down into poverty because the challenges are just too big. I find that as a country, it's almost as if we walk by... You know those nights when you're walking by and a beggar or panhandler is on the side and you don't want to stop - it seems a little dangerous anyway - so you turn as if you don't see them, and you keep going forward. Well, that's fear, and it's often understandable. That's the kind of fear I fear our country is living in right now. Too big to touch, too hard to handle - let's give speeches but not really solve the problems. Let's be sure to say that we care, but let's not do the analysis, let's not do the heavy lifting that would be required to actually change the state of affairs.

But the fear is so shockingly misplaced that it's my greatest anguish everyday. The reason it's so incredibly misplaced is that we have lost sight of how rich and capable and powerful we are to address these challenges with our technologies. We believe that those challenges would be 20 or 30 or 40 percent of our incomes; they would suck us down. We don't understand how practically addressable these problems are. Let me tell you why they're straightforward to address.

There's one great piece of good news. Thanks to people like Dr. Borlaug and Dr. Swaminathan, thanks to the science that they were empowered by, thanks to the very real truths of market forces, which can't change the light bulb by themselves but can stock a store full of light bulbs when you need them, thanks to the real power of good economics, the U.S. leadership in creating a global economy that we weren't afraid of but that we welcomed and helped to create, thanks to science that we helped to develop right here with high-yield varieties, which were taken to Mexico, taken to East Asia, brought to India - thanks to all of that, the world has made immense advances over the past half-century.

A half-century ago it would not have been possible to think about ending extreme poverty in the world. There were too many poor people, including India grappling with chronic famine, and impoverished China - two countries that alone constitute $40 \%$ of the world's population. With all the rest of the poverty around, it really was too much to take on. 
But the progress is real, and it's remarkable. China is on a wonderful track now. With its Green Revolution, with its dramatic surge of food productivity, and finally with the opening of its economy and society to the outside world under Dung Shao Ping starting in 1978, China has had indeed the fastest economic development in the history of the world. We don't have to worry about China as an impoverished country. I'd like to add, parenthetically, that we don't have to worry about China as a rich and powerful country either, because they will be our friends if we're not too scared to let that happen also.

Similarly, India is on the rise. Although it started a bit later and its economy was tied up in knots by bureaucratic restrictions, that bureaucracy didn't stop the Green Revolution. Even the bureaucracy started to change a little over a decade ago, and India, which I visit several times every year, is now one of the most economically dynamic places on the planet. Although poverty is still a tremendous problem, economic growth of $6 \%$ per year is changing things quickly.

Well, you look around the world - we've made a lot of progress. But what we need to understand is that this wonderful progress is a sign of what can be accomplished everywhere, but it is no guarantee that it is being accomplished everywhere. In the midst of this scientific and technological revolution, and in the midst of an expanding global economy, nevertheless at least one out of every six people on the planet is fighting for survival right now, in the depths of extreme impoverishment.

Most of Sub-Saharan Africa has not had its Green Revolution, and already under pressures of disease, of debts that we did not see fit to release, of tremendous geographical difficulties of being in remote landlocked, often mountainous, often highly vulnerable climates in large parts of Sub-Saharan Africa, hundreds of millions of people are struggling for survival today, unrelieved by any miracles of the market.

On top of it all, into that already profound humanitarian crisis came the visitation of AIDS, came the resurgence of malaria as the traditional drugs stopped working, came the resurgence of tuberculosis on the back of the AIDS pandemic, came the millions of children still dying of respiratory infection because they're condemned to use unsafe fuel wood for cooking, rather than modern and safe methods of indoor cooking.

Africa is dying. The diseases, the impoverishment, the depletion of soil nutrients that Pedro Sanchez is alerting us to more than any other person in the world, are taking a dramatic toll. In the last 20 years, the poorest region of the world has not only not caught up, as China and India are now doing, not only did it not make even slow progress, but it experienced two decades of disaster. Living standards are falling, food output per capita is declining, life expectancy is plummeting on the back of the pandemic diseases, and of course this creates an environment that no investor would even take a second look at. All this proves that it's possible for a whole sub-continent of 700 million people virtually to fall off the face of the planet with not so much as a ho-hum in our daily newspapers.

Markets will not come to rescue these people, because there's no market force there. When people are impoverished, when they're not even generating enough to stay alive, they 
don't have enough to buy our goods. Without that, no smart businessman even turns that direction. You can't leave this to the marketplace.

There are other parts of the world, though none with the scale of Sub-Saharan Africa, where the combination of geographical distress, remoteness, difficult climates, and history have conspired to leave people trapped in a downward spiral of poverty, disease and degradation. They include central Asia, Afghanistan (not just because of the Taliban but because of the extreme difficulties of economic progress in remote and landlocked places of that region) the Andean region, a region that I love but is utterly neglected by our country now. Take Bolivia, for example: a country that struggled with economic development and democratization for 25 years, battles the demons of impoverishment, dispossesses hundreds of thousands of people by cutting up their coca crops destined for U.S. markets because the U.S. has asked it to - only to find itself utterly abandoned by this country as its cities burn in riots, as desperately poor peasants come to protest their impoverishment, thinking that somehow it's something that their government can solve, when it is nothing that can be solved by that country alone.

Our world is one of progress juxtaposed with a downward spiral of desperation that doesn't stop on its own. We need to come to have some understanding, some self-regard for our own humanity, some more penetrating insight into what's going to really make a safer world for the United States, one freer of disease, state failure, mass unwanted migration, and a growing proportion of the world where Americans dare not travel because it's too dangerous.

The beauty, ladies and gentlemen, is that we as the United States actually said we'd do it, and I know that if it's up to the people in this room, we will do it. We said we'd do it in September 2000 at the Millennium Assembly, we said it in Monterey, Mexico, with the Summit on Finance for International Development, we said it at the Johannesburg World Summit on Sustainable Development, we said it at innumerable G-8 summits. It isn't right, or wise, for the rich to turn their backs on the poor and believe that we can live in a world of mass, unnecessary death by the millions and not pay a price by demeaning human life so dramatically. Fundamentally, we are saying that human life doesn't count, and that puts every one of us and every one of our children at risk.

Now, just a little bit of the economics that's a little bit shocking. We could solve these problems, ladies and gentlemen, truly, for less than one penny out of every dollar of our income. We could bring a billion people out of extreme poverty, we could save millions of lives every year for decisively less than $1 \%$ of our income. But we're too afraid to look at it.

I chaired a commission for the World Health Organization in 2000-2001, which was charged with actually doing the cost analysis. What would it really take to address AIDS? What would it take to address acute lower respiratory infection, childhood immunization, micronutrient supplementation, emergency obstetrical care to save the half a million mothers that die in childbirth in the impoverished countries these days because there's no doctor? How much would it cost?

Once you look at the numbers, you realize we're throwing away lives for pennies. A dose of anti-malarial quinine can save a life for a few cents, and yet many times I have been in a 
village in Malawi or Uganda or Ethiopia, to be told that the mother took the child to the clinic, but there was no quinine there - because the state system can't afford it.

In the Commission, we added the costs, we added in generous margins for management, for improved salaries of doctors and nurses so that they wouldn't all go to the United States or Europe. Africa's exporting its few doctors to our hospitals and our cities, so we included higher wages in the costing. We included computer systems so that there can be logistic supply and referrals and other things that are part of a normal and decent basic health system. We included clinics with drugs in them and basic diagnostics.

When you look at it, ladies and gentlemen, it turns out to be absolutely unbelievable. It turns out that for around $\$ 25$ billion from the whole rich world, combined with the efforts from the poor countries themselves, it would be possible to extend 49 basic life-saving and lifeextending interventions to fight those diseases to at least two thirds of the population of the poorest countries. Our world-class epidemiologists from the London School of Hygiene and Tropical Medicine estimated that doing this would avert eight million deaths per year. Think about it! We're fighting a war on terror that took 3,000 on September 11 - one of the most shocking events of modern history. Yet every single day at least 3,000 African children die of malaria. The count is probably has high as 9,000 - every single day! We haven't lifted a finger to do anything about it, nothing except speeches like the one I'm giving, which won't change anything unless it helps us together to do something.

It's fair to say that the world's leading experts on hunger issues are assembled in this room, not in hyperbole but in an absolute, literal sense. They've identified key interventions that can change the amount that a poor African household is producing, from one ton per hectare per year - not enough to feed a family and probably not enough to survive the visitation of an infectious disease - to three or four or five tons per hectare. This can be done with good agronomic practices, improved application of fertilizers, agroforestry, water management, and other things that you've all pioneered - standard practices that don't reach the poorest of the poor because they can't afford them.

The World Bank once said, "We'll make markets work. Let's cut the fertilizer subsidies." So the fertilizer subsidy was cut, and lo and behold more people died. Fifteen years later, they say, "Let's try something different."

Well, this time, let's try investing in the needs of the poorest of the poor - not giving them lectures about tightening their belts, but helping equip them with what they need to stay alive, to keep their children healthy, to enable their children to go to school, to enable the children to survive so that mothers and fathers stop choosing to have six children but feel that it's safe to have two, thereby stopping the rampant spiral of population exploding. Saving children doesn't cause a population explosion. Saving children makes it safe for families to have fewer children.

What we're doing in the UN Millennium Project is not theory, not an argument about the miracles of the market, not rhetoric, but asking what poor people need specific to their locations 
and struggles, so that they can be equipped with the means of survival and so their children can be equipped with the means of education and empowerment to join the world community.

Our costing work, though still incomplete, estimates that $\$ 25$ billion for health might be tripled if you add in the challenges for hunger, rural roads, rural electricity, or liquid petroleum gas canisters so that households are cooking with safe fuels rather than chopping down rain forests, and helping the poor achieve access to safe water. All this might cost the rich world $\$ 75$ billion - it used to sound like a lot until the cost of the war on Iraq belittled these numbers. Those $\$ 75$ billion, by the way, that's not for the US to do alone, that's for the whole rich world to do. The U.S. share would be about one third, about \$25 billion a year for our share of helping a billion people escape from poverty and ending this cycle of mass death. $\$ 25$ billion - it's five months of our troops in Iraq. That's what we're talking about. It's 30 cents out of every hundred dollars of our income. We could keep $\$ 99.70$ for us, and put aside 30 cents. $\$ 75$ billion is just .3 of $1 \%$ of the GNP of the rich world (which is $\$ 25$ trillion dollars now), 3 cents out of every $\$ 10$, 30 cents out of every hundred dollars of our income.

What are we doing, ladies and gentlemen? We're not doing that. However much you believe, rightly, that Americans are extraordinarily generous, because we are - we're not making those decisions right now. We haven't been asked to make those decisions by any president for decades. But it turns out that we found $\$ 150$ billion for the war - maybe we should stop and think about what would really make us safe in the world.

I want to ask something of all you good people, because you have a huge role to play. I understand that you all get visited by some of those candidates every few days. They come to your homes, they have coffee with you. I understand they meet each of you six or seven times. I'd really like you to ask them a question - not just what does all of this mean for me, or what does it mean for us, but, "What are you going to do for humanity, Mr. Senator or Mr. Congressman or Mr. Governor or Mr. General?"

We in the United States we know that this is not the kind of world we need to live in. It's not the kind of world we feel safe in. We know our troops aren't going to solve these problems. It's not the kind of world we want to live in. Your presence here assures me that that's the case, and I think it's the case across the U.S. I think together we can do a wonderful thing for the United States and for the world by leading a very noble cause to end this scourge of extreme poverty and to do it within our generation.

Thank you very much. 